\title{
国内炭によるコークス製造 \\ Manufucturing Coke from Domestic Coal
}

UDC $662.24: 622.333(52)$

\author{
正会員山村 礼 次郎 \\ Reijiro YAMAURA
}

\section{1. 石炭採掘業の採算性}

数年来わが国の石炭鉱業はいまだかつて見ない苦況の 中にあつて、ひたすらな努力により採掘原価の低減計 つている。

企業の合理化，採炭の機械化，設備の近代化，新技術 の導入などがこれであり，政府の諸対策もこれらを行政 的に強力に推進している。

しかし，わが国の石炭鉱業が企業内容としている石炭 の採掘, 販売事業にういて言えば，開発が進み出炭が増 加するにつれて坑内領域の拡大, 採掘深度の増加, 自然 条件の悪化などは宿命的であり，したがつて上にあげた ような対策はまず原価の上昇を抑えた後にはじめて効果 を発揮するものである。はつきり言えば，鉱山業におけ る採掘原価は漸次上昇すること注避けることができない と考えなければならない。

しからば，近年のエネルギー市場の激しい変動の中で 石炭業界がどうして採掘原価を抑制し, さらに低減しえ たのであろうか？もちろん，一言では言いつくしえぬ 多くの理由があるのであろらが，客観的な統計数值に上 つて，一つ坴特徽的に見ることができる。

第1表 わが国炭鉣の採掘条件の推移

\begin{tabular}{|c|c|c|c|c|c|}
\hline 年 月 & 30.3 & 36.3 & 37.3 & 38.3 & 39.3 \\
\hline 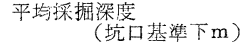 & 330 & 354.7 & 361.8 & 368 & 378 \\
\hline 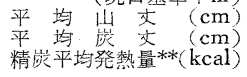 & $\begin{array}{r}171 \\
132 \\
6,164\end{array}$ & $\begin{array}{r}188 \\
141 \\
6,210\end{array}$ & $\begin{array}{r}197 \\
152 \\
6,230\end{array}$ & $\begin{array}{r}205 \\
157 \\
6,240\end{array}$ & $\begin{array}{r}216 \\
173 \\
6,290\end{array}$ \\
\hline
\end{tabular}

すなわち，第 1 表はわが国の炭鉱の採掘条件の推移を 示す数值であるが, 数年来稼行炭層の平均山丈, 平均炭 丈は共に厚くなつてきている。これ滛済的に採算困難 な炭鉱が休廃止されるばかりでなく, 生き残る炭鉱自体 も層厚が厚くてハサミの少ない収益性の高い炭層に出炭 が集中し，収益性の悪、炭層は採掘されなくなりつつあ ると，傾向的に判断できる。言い換えれば，前年までは 稼行可能であつた炭層も本年には放棄するといつた稼行 対象炭量の縮少によつて, 収益性を辛うじて維持してい るものと考えざるをえない。

また，精炭平均発熱量も年々わずかながらも上昇しつ

* 石炭技熦研究所企画部長
つある。選炭技術の進歩と消費者側の高品位炭に対する 要求にのみ原因があるとすれ垶いであるが，この傾向 も良質の炭層に採掘対象を移行することによつて採掘原 価の抑制を計つているものと想像されらるのである。こ のことは，選炭歩留が近年上昇しつつあることからも推 論できる。

これらの事実は, 石炭採掘事業の採算性が年々と悪化 する一つの宿命を暗示し, 貴重な石炭資源を未利用のま ま放棄し，石炭鉱業の寿命妾自ら短縮させていると言わ ざるをえない。

しからば，炭鉱はレかにしてこの窮境を打開すべき か? その解答を見出すために, 戦後奇蹟的と言われる 目覚ましい発展を遂げてきたわが国の産業界の動きを見 直して見よう。

\section{2. 戦後のわが国鉄鋼業に見られる特徵}

一例としてわれわれ石炭鉱業に最も関連の深、鉄鋼業 の動きを取上げれば，すでに粗鋼生産量は昭和 39 年に 3,150 万 $\mathrm{t}$ と西ドイツを抜き，世界第 3 位を占める世界 的規模に達した。

このような急速な発展を遂げるに至つたのには，第二 次大戦後の世界経済の大きな変革あるいは大勢孛速やか にとらえて設備の近代化，大容量化を計つた鉄鋼業界の 達眼, そのほか数多くの理由字上げうるであろらが，筆 者の見解によれば，いかなる企業といえどもその発展に 当つて当然なされるはずの経営内容の変化が，きわめて 円滑かつ適切に行なわれてきたと考えられるのである。

すなわち，戦前はほとんど官営の日本製鉄だけに限ら れていた鉄鋼一貫作業の事業形態をいずれの会社も採り 入れ, しかも大胆に最先端の技術・設備を採用して近代 的で大容量の製鉄所学建設した。

また，特にあげなければならない特徴は，銑鉄・粗鋼 の生産だけにとどまらず戦後の産業界の飛躍的な発展に 々もなつて需要の伸びてきた薄鋼板, 表面処理を行なつ た各種鋼材, あるい注種々の特性を持つた各種材質・形 状の特殊鋼材など, 市場の動向に合わせた数多くの二次 加工品・三次加工品の製造にまで事業内容ならびに範囲 が拡大してきたことである。

これは単㳊需要者側から刺激されあるいは要求されて 拉大してきたと見るべきで流く，むしろ鉄鋼業界自ら 
が市場の将来を見通して常により収益性の高、製品の製 造を自社事業に採り入れ，その製品の販路を製造業者自 ら進んで開拓して経営内容を豊かにしようと努力してき たと判断すべきであろう。

さらに，その曙光が見え出した段階とは言えようが， 多年の経験によつて高めえた製管技術ならびに設備技術 を活用してプラスチック管の新規事業へ進むとか，ある いは将来の鉄鋼原料がラテライト鉱に変わることを予測 して，原料的関連してくるであらうアルミニウム精練 あるいは軽合金工業との結び付きを企業的に発展させよ うとする動きも，同様に企業経営をりり収益性の高いる のに仕上げようとする意欲の現われ之見て良い。

このような企業経営・事業内容の発展的変革は, 単に 鉄鋼業のみに見られるものではない。戦前から世界的に 名の知られた日本の紡績業が綿紡・麻紡から脱却して化 学工業と結び合成繊維のすぐれた特性と多年育て上げて きた紡績技術によつて，ふたたび企業の隆盛を克ち得て いるのもその例と言えよう。

これらの実例をあげるまでもなく，企業とは常仙自ら の技術と経験を生かしながら事業内容をより收益性の高 いものに変化させて行くべきものであり，その際まず考 えられるのは，自らの製品をより高次のものにするこ之 によつて消費者にわたる最終製品に近つくというここで ある。

\section{3. 鉄鋼業におけるコークス事業}

さらに，石炭業界の直接関連するコークス製造事業に ついて考察して見たい。

わが国に㧍ける重工業の発展の仕方ならびに石炭資源 の特殊性の故に, 各国と全く傾向を異にして, 炭鉱が二 一クスを自ら製造することはほとんど行なわれず，大部 分は消費者側で行なわれてきたことは，衆知の事実であ る。

第 2 表に昭和 39 年度における産業別荷渡状沉中，原料 炭大口消費先の分を示したが，その53\%が高炉製鉄用上 して鉄鋼業界で消費されている。

第2 表 昭和39年度に新ける原料崖の 大口消費の動向*

\begin{tabular}{|c|c|c|c|c|}
\hline & & & 国内 岸 (t) & 翰 入宸 $(t)$ \\
\hline $\begin{array}{l}\text { 全 } \\
\text { 高 } \\
\text { ב } \\
\text { ガ }\end{array}$ & 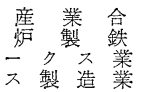 & $\begin{array}{l}\text { 棓 } \\
\text { 用 } \\
\text { 用 } \\
\text { 用 }\end{array}$ & $\begin{array}{r}12,152,250 \\
6,403,836 \\
2,280,836 \\
3,097,726\end{array}$ & $\begin{array}{r}12,451,526 \\
11,569,477 \\
214,257 \\
666,758\end{array}$ \\
\hline
\end{tabular}

*「石孷統計月報」昭 40.3 “産業別荷溃”ょり

ところで，前項に述べたよらな鉄鋼業の経営内容の変 化が，いままでの製鉄所におけるコークス製造事業に対 して大きく影響するこさは，当然之考えなければならな i。
その影響の主な点を上げると次の通りである。

（1）従来の製鉄所では，コークス炉，高炉，平炉， 転炉などによつて，鉄鋼一貫作業を行なう場合，鉄鉣石， コークス，ガス，銑鉄，屑鉄などの物質収支にある一定 のバランスがあり，またその間の熱収支の経済バランス のために乾留設備の一定規模が絶対必要と考えられてい. た。しかし上述したように，鉄鋼業の企業内容が多角化 し大規模化するにともなつてコークス，ガス，その他の 製造設備が必ずしも製鉄所内の全体の収支とバランスす るとは限らず，むしろ重油による熱源などを含めた計算 による設備規模ならびに配置が必要となり，またそれが. 有利さされるに至つた。

（2）事業内容が広範囲となるにつれて，より収益性 の高い事業や工場設備の投資の重点が移動して行く傾向 となる。

（3）同様な理由で，広大な設備面積を必要とする場 合に，収益性の高、設備への投資が優先することにな る。

（4）乙かも, 收益性の低い事業の場合は設備単位を より大きくして経済効率を高めなければならないが，こ 机は上記の物質収支，熱収支のバランスをますますくず すことになる。

（5）乾留事業のようにコークス,ガス, タール，そ の他の製品のうち特に石油・天然ガスと競合する製品に ついては，競争力を強めるには製造単位を一層大きくす る必要がある。

（6）特にわが国のように, 狭险な既成工業地帯内に ある鉄鋼所ではすでに労働力・敷地・用水・その他が漸 次限界に近づきつつあり，事業自体が集約化，自動化さ れた効率の高いものでなければ成立し難くなりつつあ, る。

以上述べたような情勢から，乾留事業が製鉄業と一体 不離のものであるという従来の観念が必ずしも必然のも のではなく, 鉄鋼等の企業の発展にともなつて乾留事業 などは，構想を新たにした形で経営されるべき事情が生 れてきたと考えられるのである。

\section{4. コークス製造技術の発達}

わが国では石炭の乾留によるコークス製造技術は戦前 から, 強粘結炭の不足に対処して輸入強粘結炭と国内炭 の配合による製鉄用コークスの製造に努力が向けられて きた。しかし第二次大戦後世界的にコークス用炭の範囲 桩大を計る研究が活発に行なわれ，着々とその成果を上 げるに至つた。

そのらち，現在世界のコークス生産の大半で占めてい る室炉法に限つてすでに内外において企業化にまで進ん。 だ技術を次にあげてみよら。 
（1） コーライト配合法，一般炭配合法

石炭の分析成分, 加熱による軟化溶融性, 流動性, 膨 張性, 収縮性, 粘結成分量などの各種特性をとらえて, 強粘結炭をべースとしてコーライト・粉コークス・膨潤 炭亦るい注一般炭を配合して十分な強度を有する製鉄用 ニークスを作るものであり,この際, 装入炭の粒度, カ サ密度, 乾留速度なども二次的に大きく影響する。

ニーライト法は古く戦争中から室蘭製鉄所において実 操業に利用されており，また一般炭配合法も同じく室蘭 製鉄所で一般炭 $5 \sim 10 \%$ 。配合して十分な強度のコーク スを製造することに成功し，1力月の高炉操業も行なつ た之言われている。また本法によれば輸入低揮発分強粘 結炭の配合割合が高くなつた場合の乾留時の膨張圧抑制 にも効果があるとされている。

(2) 選択破碎法

SOVACO 法あるいは Burstlein 法とも言われ，フ ランスの Burstlein が発明し, フランス, ドイッ, ‘ メリカ, その他で企業化されている。本法は石炭を構成 する組織成分の破砕性の差違を利用し，粘結性に富むビ トリット抢よびクラリットは細かく破砕せず，不活性成 分に富むドリットならびにフレジットをなるべく細かく 破砕して粘度調整を行ならことを特徴としている。した がつて，粉砕とフルイ分けを組合わせた設備フローシー トからなり，強粘結炭の節減とコークス用炭の範囲拡大 を計ることができる。

\section{（3）油添加装入法 (オイリング法)}

装入炭に重油 $0.2 \sim 0.5 \%$ を添加することにより，カ サ密度の増加と共にコークス強度を增し，あるいは強粘 結炭の配合割合を減少することができる。また油添加に よつて乾留化成品の収量も増加するとされている。すで に方が国の各製鉄所においても実炉操業に採用されてい る。油添加は，石炭の取扱操作を容易にし粉ジン抑制， 凍結防止等にも效果があるので，各国でも利用されてい るよらである。特炭鉣で脱水・輸送・取扱いが困難な た利用度の低、微粉炭を山元において油添加する技術 吕採用されるならば，生産者・消費者の両者を通じて大 きく効果を上げるものと期待される。

\section{（4）予熱装入法，乾燥装入法}

装入炭をあらかじめ $100 \sim 250^{\circ} \mathrm{C}$ に予熱してからコー クス炉に装入する方法で，強粘結炭の配合割合を節減す ることができ，かつ装入密度が増し炭化時間が短縮され るためにコークス炉の生産性が増大する利点がある。

石炭技術研究所は数年来, 流動炉に上る予熱法を採用 乙, $200 \mathrm{~mm} \phi, 700 \mathrm{~mm} \phi, 600 \mathrm{~mm} \phi$ 等の流動炬によつて 実験をかさ称，その効果を確かめた。また昨年来，北炭 夕張の化成工業所の協力をえて, 同所の実炉について子 熱炭の運般取扱いあるいは装入時の難易などを確かめ，
また本年に入つてから強粘結炭配合等のコークス化性の 変化を確認しつつある。すでにフランスでも本法による コークス化が進められており，最近ではアメリカにおい て350t/h容量の流動炉による予熱装入法が採用されたと の情報が伝えられている。

(5) 成形孷装入法

成形乾留法は古くから各国において研究され, わが国 でも石炭綜合研究所が行なつた二段乾留法, 八幡製鉄所 が行なつた国内炭各種 $85 \%$ と輸入強粘結炭 $5 \%$ にピッチ 約10\%を加えた成形炭による乾留法等があるが，いずれ も室炉に対する適用は困難であつた。

これに対して，ドイツのカールスチル社が開発した方 法は，バインダーを加えず汇高圧成形し，室炉装入時の 一部破砕を利用して室炉内におりる装入炭の塊粉率を調 節し，コークス化を行ならものである。すでにヨーロッ パでは数力所の操業を見ており,わが国では最近に鉄鋼 協会の手で八幡製鉄所において国内炭による本法の効果 を確かめつつある。

以上のほか, スタンピング法も三菱化成黒崎工場で採 用されており，実炉によるコークス製造技術に限つても すでに企業化を見ている各種の技術が開発され，従来考 えられていたようなコークス製造事業の経営条件や立地 条件のせまさは克服されつうあると考えることができ る。

\section{5. 石炭鉱業のコークス製造事業進出の可能性}

以上，鉄鋼業を一例に上げてその企業発展の動向，な らびにそれに伴うコークス事業の置かれている立場を述 ベ，さらにコークス製造技術の最近の発達状況を概説し たが，このような情勢判断の下にわれわれ石炭鉱業が今 後発展する方向として，上述したコークス製造事業との 結び付きが可能と考えられないであるらか？ 筆者はそ の可能性を確信し，その理由を次に上げて見たい。

\section{技術的には：}

（1）国内では強粘結炭が不足し，国内炭の単味によ る製鉄用コークス製造が不可能であることは，現在では コークス製造事業に対する致命的欠陥とはならない。大 量のコークス需要に対していずれの国といえども，多種 の石炭の配合によらざるをえなくなつている。したがつ て，石炭鉱業が自らの生産する石炭と配合性の良い炭質 の石炭を選しで輸入することで，良質のコークスを経済 的に製造することができる。

（2）すでに企業化されている種々の製造技術を選択 することによつて，コークス用炭の範囲を拡大すること が可能であり，国内炭の大幅な活用が可能である。

（3）石炭の生産技術と利用技術を直接に結び付ける ことによつて，いずれの分野にも有利となる新技術の採 
用が可能となる。たとえば，炭鉱で脱水，取扱いが困難 なため現在は経済的に利用が困難である微粉炭に対して 油添加脱水を行ならならば，一定湿分で取扱い容易な含 油炭を製造することができ，この製品はコークス事業， 発電事業においても湿分変動による作業障害を除き，か つコークス製造技術あるいは然焼技術に対してもより有 効に作用することが考えられる。

\section{事業経営的には：}

（4）石炭の採掘販売という従来の単一製品企業か ら, コークス, その他多種製品企業に発展することによ つて, 企業経営の多角化が可能となり, 運営の伸縮性が 大となる。

（5）労務費率の高、石炭採掘事業から，労務費率の 低、生産性の高、事業へと, 経営内容が改善される。

（6）今後のコークス需要の増大を考慮すれば, 既存 の製鉄所コークスや専業コークスとの共存が可能と見込 みらる。

（7）近代化された大規模コークス工場によつて，十 分経済性法確保できる。

（8）特に, 化成品については生産単位を大形化する ことによつて，各種利用工業との結び付きが経済的に可
能となる。

（9）産炭地に近、臨海地帯に大コークス工場を建設 することにより，原料・製品の輸送も有利となり，国内 炭の経済性を高めることができる。

\section{むす び}

石炭鉱業注在，石炭採掘原価の上昇によつていよい よ企業内容が悪化しつつある。この状況のもとで単に企 業を縮小し，採算性の良い炭鉱のみを残し，採算性の良 炭層のみ棌掘を集中しても，一時的なびほう策でし かありえない。

石炭釷業の長期安定をみるには，石炭資源の長期利用 分野を正確に把握し，その利用分野を石炭鉱業の企業内 容に取り入れ，その総合収益の中から石炭採掘事業の改 善を計る以外に，対策はないと考える。

その大きな対象となるものが，本稿で述べたコークス 製造であり，また石炭火力による発電である。

これらにより石炭鉱業の前途に明るい目標を見出し， 新しい積極的意欲を燃やすことによつて，さらに石炭採 掘事業自体にも新しい活路が開かれてくるものと確信す 万。

UDC 622. 333-136: $662.87: 004.14$

\title{
微粉炭の有効利用に関する研究 Studies on Effective Use of Fine Coal
}

\author{
正会員島野広 \\ Hiroshi SHIMANO
}

\section{1. 緒}

炭鉣における坑内機械化の発達進展に伴い，微粉炭の 産出が急激に増えてきた。この傾向は生産統計等にはあ まり顕著に表われていないが，銘柄としての微粉炭の生 産量は，そのときどきの市況によつて左右されることが 多く，また原料用炭や一般用炭に混じつたまま送炭され る量も相当あるからであろう。しかし，近時微粉炭の回 収技術の進歩ならびに設備の増強にもよるが，現実に各 炭鉱における微粉炭の産出量が激増の傾向にあることは 明らかである。

微粉炭は選炭廃水からの回収，ならびに品位向上のた めの選別に, 中小塊または粉炭サイズの石炭に比し,数倍 の設備が必要であり，選別効率も回収率もともに低い。 その上粒度が細か、ので, 機械脱水だけでは脱水率に限 度があつて，これを使用する工場での取り扱いや運搬等 の過程で，側壁固着，シニ一下閉塞，あるいは厳寒季凍 結等のトラブルを生じ易く，同品位の粉炭に比し 1,500

* 石炭技術研究所理事 第 2 研究部部長 $\sim 2,000$ 円 $/ \mathrm{t}$ 程度の炭価の開きがある。また電力用炭に 対しては粒度規正があり,一定限度以上の微粉炭の混入 は許されない。また原料用炭に対しても, 粒度規正はな いが，湿分規正の関係で, 脱水不十分な微粉炭の混大量 に注京のこからら限度がある。

微粉炭は, このように外部から, 廃品回収物として, また石炭の屑としてしか評価されていないが，最初に述 べたように, 近時その産出量は著増の傾向にある。した がつてこの屑と見られる微粉炭を加工改質して，少なく も同一品位の中小塊や粉炭なみに, あるいはそれ以上に 評価されるように経済的に処理する方法があれば，炭鉱 経営の合理化の上に奇与するところすこぶる大なるもの があると考えられる。

当研究所は, その意味に打いて, 創立以来この問題に ついて種々研究を行なつて来た。また現在も引き続き研 究実施中である。以下その結果についてのべたいと思 う。なお試験研究の方法等は後尾に示す諸文献にすでに 詳しく報告されており，また現在続行中の補追試験終了 後に, あらためて詳細な報告書を発表する予定であるの 